\title{
Brzezinski and Mackinder theories: Role and influence on the political construction of Eurasia
}

\author{
A. Singh \\ Institute for Global International Relations, Aoyama Gakuin University, \\ 4-4-25, Shibuya, Shibuya-ku, Tokyo, 150-8366, Japan
}

For citation: Singh A. Brzezinski and Mackinder theories: Role and influence on the political construction of Eurasia. Vestnik of Saint Petersburg University. International Relations, 2020, vol. 13, issue 4, pp. 527-535. https://doi.org/10.21638/spbu06.2020.407

International relations theories act as the guiding lantern to provide a simple yet powerful description of international phenomena such as war, expansionism, alliances and cooperation. Thus, the primary objective of this article is to analyze international relations theories, their roles and influence on global politics hereby bridging the gap between the abstract world of theory and the real world of policy. The article utilizes the Grand Chess Board and Heartland theories on the regional geopolitical processes in Eurasia. The core argument of the article is that theoretical perception creates regional identities, and states use these emerged identities to influence geopolitical traditions. The Grand Chess Board theory of Brzezinski states that in order to sustain its position as a global hegemon, the US needs to control and manage Eurasia. Moreover, this article analyses American foreign policy in Eurasia under the umbrella of the Grand Chess Board theory. The Chinese strategy towards Eurasia through the prism of Mackinder's Heartland theory is also explored. By analyzing initiatives such as One Belt One Road (OBOR), the Shanghai Cooperation Organization and the energy push in Central Asia, this article can serve as an examination into the Chinese taking up the mantle of the heartland to emerge as the land power of the $21^{\text {st }}$ century.

Keywords: geopolitics, foreign policy, international relations theory, China, Central Asia, Eurasia, USA.

\section{Introduction}

Theorist propagates specific ideas and politicians use it, or either way to fulfil some political agenda of the individual country its strategist come out with forms of theories. In order to support their political invasion, territorial expansion states use these traditional notions to fulfil their motives. Theories not only construct an environment in favour of hegemon states but also support their role as a hegemon and even grant them the right to be a hegemon.

There were a lot of thinkers in the past who had a strong influence in practical policies of the state in their time and inspired regimes for expansionist policies, geopoliticians such as Friedrich Ratzel, Karl Houshofer, Mahan, Mackinder and Spykman are some of those thinkers. Ratzel was of the view that there had always been competition for space among people and there is a correlation between culture and physical environment of the people. In the first stage, people adapt themselves to the environment and in later stage develop environment according to them. In his one of the important works "Politische Geographie", Ratzel states that development of state goes hand in hand with the development

(C) St. Petersburg State University, 2020 
of the people. Thus postulating the notion of Lebensraum (Living Space) the idea which postulated that land was essential for the survival of people [1]. Kejellen introduced the concept of Geopolitics as the "doctrine of the state as a geographic organism". He stressed the importance of the interplay between geographic factors and material resources of power for the relation between states [2]. Popularized by Haushofer, geopolitics became a tool, and Lebensraum a mean for expansion, this concept was used by Nazi Germany to justify their territorial expansion, during World War II.

The image formed by the continuous assertion in academic discourse influence the strategies, goals and behaviour of political actors, there had been times when foreign policy based on these constructions was proven to be incalculably successful if they are based on solid geopolitical settings, and if not they become a tool to create anarchy in the region which is very much evident by the above-given example [3]. Thus, geopolitics does guide states to formulate policies and action, in consensus with their geographical settings, for example whether to focus on sea or land power, or a better spatial placement for protection, or enclosed within a checkerboard [4].

As they say "Past is the Key to Present", the author supports the argument taking statement from Geoffrey Sloan's (2017) [5] book titled as "Geopolitics Geography and Strategic History" in which Sloan mentioned that, "Classical geopolitics provides the flexibility and adaptability to enable policy makers to understand and react to emerging $21^{\text {st }} \mathrm{Cen}$ tury geopolitical realities". The article uses classical geopolitical theories since they provide a logical connotation between location of states, regions, resources and their influence upon foreign policy making [4]. Thus, chief objective of this paper is to analyse the role of Mackinder's Heartland and Brzezinski's Grand Chess Board theory in shaping perception about the Heart of Eurasia.

Coming towards the main theme of the article, the study goes beyond the geographical settings to view geopolitical settings which create an image and brings out the region on global space. Formation of this image is also directly related to the philosophy which directs the interest in the region. For example, Western academia labelled Central Asia, the heart of Eurasia as the Heartland, Chessboard and Greater Central Asia, to map this part of the world which was essential to be controlled to become a global hegemon. On the other hand, Russians came up with the concept of Eurasianism - a theory which provides Russia with a special role in Eurasia and stresses close philosophic, cultural, and spiritual ties, also Near Abroad which permits Russia the special privileges in this region [6].

From a historical and geographical perspective, the region's location and rich mineral resources had attracted many outside powers and at one point of time, this region was the "focal point" for different competing civilizations. Owing to the central location of this region, it can be precisely called as a zone of convergence of the major geo-cultural regions of Eurasia, which with its secular interactions bridging both continents. The host of Geopolitical thinkers like Mackinder, Mahan, Brzezinski, elucidated the importance of the region into the following frameworks: trade routes, a bridge between Europe, Russia and rest of Asia, a middle way to Indian Ocean, resources and goods of high demand. Mackinder argued that although geographic environment does not define policymakers' choice but it conditioned them, thus correlation between geography and human agency cannot be ignored [7]. Mackinder inspired generations of strategic studies across the globe. In the post war era, the American strategist continued to view the world as seen by Mackinder to proliferate their foreign policy of containment in the Eurasian landmass. Especially after 
Soviet collapse there has been strong revival of Mackinder's ideas to justify competition for influence in Eurasian Heartland [8]. Later on, Brzezinski carried forward Mackinder's ideas during post-cold war which acted as the cornerstone of foreign policy towards Eurasia during Clinton and Bush administration.

The article uses deductive approach discussing Heartland and Grand Chess Board Theory to understand the geopolitics of region as a whole and locational importance. According to American Heritage Dictionary, theories represent, "systematically arranged knowledge applicable relatively in wide variety of circumstances especially a system of assumptions, accepted principles and rules of procedures devised to analyse, predict or otherwise explain the nature or behaviour of a specified set of phenomena" [9]. The analyses will use descriptive process to drive conclusion.

This article will investigate how geopolitical theories have shaped the perception about Eurasia and particularly Central Asia in international system. I would examine theories of Mackinder and Brzezinski as these writers not only provide comprehensive analysis of the role of the Eurasian Heartland in world politics, but also provides strategies to pursue in the region.

\section{Mackinder's Construction of Eurasia}

Sir Halford Mackinder the British Geopolitical thinker in his articles titled, The Geographical Pivot of History and Democratic Ideals and Reality laid emphasis on the geostrategic importance of Eurasia and labelled the region as Pivot Area and Heartland. The Pivot which included Volga, Amu Darya, Syr Darya, Yenisey and Aral and the Caspian Sea, was unassailable to attacks by sea power and capable of supporting a huge population in itself [10]. He mentioned "In the industrial age, the natural resources of Central Asia - The Great Pivot - are so vast that it will serve as the geostrategic instrument for the state that controls it to become the empire of the world" [11].

Giving importance to the Central location of pivot area Mackinder suggested that the state which would dominate the Heartland would possess the necessary geopolitical and economic potential to ultimately control the world Island and the world eventually [10]. Mackinder unwrapped the hidden dynamics of Eurasian politics and advocated a very different position of its Heartland. Since 1904 till present Mackinder's theory have been active in the academic sphere in different ways.

Emphasizing on the security of each state on planet earth, Mackinder wrote, "Every explosion of social force, instead of being dissipated in a surrounding circuit of unknown space and barbaric chaos, will be sharply re-echoed from the far side of the globe, and weak element in the political and economic organism of the world will be shattered in the consequence" [10, p.422]. Very much ahead of his time, he notified in his article about the conventional nature of state borders that the occurrence of an event in one part of the world would influence the other parts as well [12].

It was in 1943 when Mackinder published his last paper in which he comprehended that after World War II Soviet Union would develop as the greatest land power of the planet earth with control over heartland and highly strong strategic defensive position. This theory played an important role later on in 1946 when George Kennan came up with the policy of Containment. Mackinder and Kennan concept became fixed in the American policy and proliferated with the formation of NATO in 1949. Strengthened by massive 


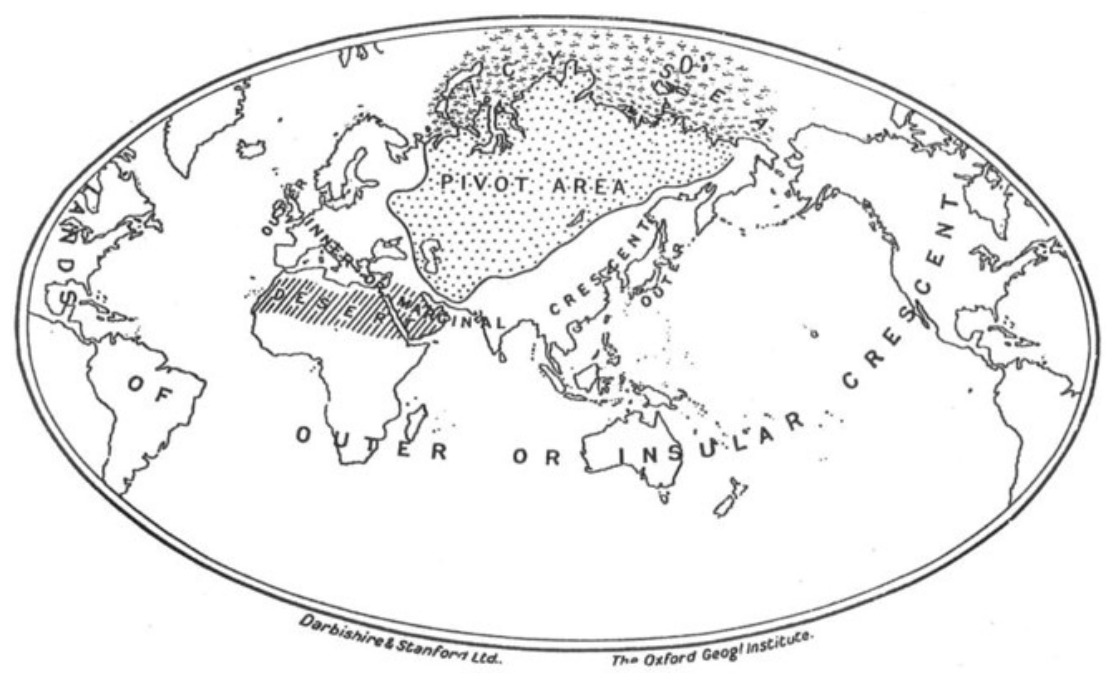

Fig. The Geographical Pivot of History: Map of Heartland Theory

Source: https://www.sott.net/article/276668-Geopolitics-of-Empire-Mackinders-HeartlandTheory-and-the-Containment-of-Russia.

sea power and even more, potent air power, the policy of containment achieved its goal with the disintegration of Soviet Union in 1991 [13].

In 1988 President Regan presented report titled, National Security Strategy of the United States of America to the congress about the geopolitical and military policy of US. The report assessed American foreign policy of Cold War in following words:

"It is the conviction that the United States' most basic national security interest would be endangered if hostile state or group of states were to dominate the Eurasian landmass- that area of the globe often referred to as the world's Heartland. We fought two world wars to prevent this from occurring. And, since 1945, we have sought to prevent the Soviet Union from capitalizing on its geostrategic advantage to dominate its neighbours in Western Europe, Asia, and the Middle East, and thereby fundamentally alter the global balance of power to our disadvantage" [14].

The Heartland theory offered the logical ground for United States cold war foreign policy. It helped the US policymakers during a post-war period to prepare an environment in which Soviet Union would be restrained on the flanks [15]. Passing from various time frame the Heartland of the world gained importance for other emerging local powers. During the cold war, it was USSR which the US wanted to contain and now it is China which is penetrating in the region with all possible means.

\section{Through the lens of Mackinder's theory Chinese strategy in Eurasia}

Chinese strategists are following steps of Mackinder's theory through the channel of strong ties with Russia to command Eurasian Heartland in order to challenge American maritime power. The study explores the adjoining area of the Caspian basin and Central Asia as the heart of the Heartland. With 3700 kilometers of joint border with Central Asia, the very first strategic motivation of China in this region was to stabilize its north-western frontier and create a constructive peripheral situation, by handling separatism and re- 
ligious extremism of Xinjiang-Uygur Autonomous Region of China efficiently. Thus by strengthening its relationship with Central Asian countries, China would suppress these elements to a certain degree [16].

Apart from fighting terrorism, separatism and radicalism and expanding its economic interests, the strategic objective of China is to check Sino-US rivalry over the Eurasian chessboard. Chinese President $\mathrm{Hu}$ Jintao stated, "The US has strengthened its military deployment in the Asia-Pacific region, strengthened the US-Japan military alliance, reinforced the strategic cooperation with India, improved relations with Vietnam, inveigled Pakistan, established a pro-American government in Afghanistan, increased arms sales to Taiwan and so on. They have extended outposts and placed pressure points on us from east, south and west. This makes a great change in our geopolitical environment" [17]. Chinese leadership not only wary of US presence but also of US allies and International Organizations like NATO and World Trade Organization which are dominated by the United States. US attempts of containing Russian and Chinese influence in Central Asia have been clearly evident to Chinese leadership giving rise to economic and political differences [18]. Thus, China took various initiatives to curb the American influence and its presence in the region and postulate counter attack to its various proposals through different initiatives. The cornerstone of China's Empty Fortress strategy for Eurasia is the Shanghai Cooperation Organization (SCO), which has grown in last 15 years into a multicultural, multifaceted organization involved in a host of security issues ranging from energy and economic security to counter-terrorism and border security. The SCO a permanent intergovernmental international organization has not only attracted Central Asian states but other regional players also. It was created on $15^{\text {th }}$ June 2001 in Shanghai in the presence of Russia, China, Kazakhstan, Kyrgyzstan and Uzbekistan [19]. With the purpose to challenge American hegemony, SCO is serving as anti-NATO bloc to counter NATO expansion into post-Soviet sphere.

Accompanying Russian objectives for the region, China is following the legacy of Mackinder's theory by forming ties with Russia to control the Eurasian Heartland in order to challenge American maritime power [20]. Abilov claims that Heartland theory of Mackinder overlaps the Caspian Region, highlights the persistent or perpetual significance of the theory through the ongoing power rivalry over Heartland. In this sense with ever-increasing Chinese penetration in Eurasian Heartland (Central Asia) through various means, it can be analysed that, Chinese involvement would emerge as a potential challenge for both Russian and American interest in the region as well as illustrating a potential shift in the utility of Mackinder's theory [21].

Defensive aspects of Chinese engagement can also be connected to China's economic concerns, Chinese strategist may view Eurasia as the strategically significant preference to focus and invest in. Because natural resources of Caspian basin may be proven as a better option of Middle East oil which is transported by maritime routes that can be threatened by a potential blockade from the Americans. It is the assertion which illustrates the continued worth of Mackinder's theory in contemporary world politics that by forming a strong alliance on the largest landmass of planet earth, it would be easy to surpass any sanction or blockade imposed by maritime rivals. 


\section{One Belt One Road (OBOR)}

Proposed by Chinese president Xi Jinping in 2013, One Belt One Road (OBOR) initiative aspires to connect people all over the world. It comprises two major programs entitled Silk Road Economic Belt and $21^{\text {st }}$ century Maritime Silk Road. This paper focuses especially on the land over "Silk Route" passing through continental Eurasia. The Asian Infrastructure Investment Bank (AIIB) was opened with its start-up capital of USD 100 billion to finance the OBOR initiative [22]. The OBOR initiative aims to intensify Chinese influence over Eurasia, as it will offer the economic, cultural, political and strategical potential to the countries besides the Belt and Road routes. Receiving global attention, Belt and Road initiative is a reinvention of the ancient Silk Road, which will prompt the massive infrastructural development on the OBOR route, through new highways, ports, and pipelines and would connect countries of Southeast Asia, East Asia and Central Asia to West Asia and Europe.

In the $21^{\text {st }}$ century modern day growing power of the world, China, is focusing on land geopolitics rather than maritime to increase its influence following the legacy of Mackinder. Stressing upon the relevancy of Mackinder's theory Harper states that in the current political scenario the threat of maritime blockade and how the OBOR programme has potential to lessen this by preventing Chinese trade off maritime routes by the construction of land routes connecting East and West corners of Eurasia [20]. By forsaking the traditional maritime routes, Chinese trade will be able to access an alternative route which avoids the sea lanes dominated by the US.

Utilization of land route will make it difficult for the US to disrupt Chinese trade, waning its navel trump card which has served as the cornerstone of American strategy to establish its hegemony. We can analyse in the present context it was the above-mentioned benefit which Mackinder elucidated in his work, the challenges put forth by land power to the maritime power.

Mackinder in his theory postulated that full development of land routes such as roads and railways would enable land powers to grow at their own without and outer dependency and would provide the niche over maritime powers. Economic gains are obviously the most important factor when any state diversify its potential strategies, so as for Beijing whose major concern to increase its influence over heartland is to access its natural and strategic resources.

SCO, OBOR, AIIB and other initiatives indicate Chinese willingness to show leadership in Eurasia. In recent years, Beijing following the policy of cooperation with Russia to counter the United States in the region. It is also increasing its soft power in the region through cultural exchange.

\section{Brzezinski’s Grand Chess Board Theory}

Zbigniew Brzezinski an American political scientist and former national security advisor to the US government in his most noted book titled, "The Grand Chess Board: American Primacy and its Geostrategic Imperatives", refers Eurasia as the "Grand Chessboard". In his book Brzezinski claims that Eurasia is the key to global primacy and a mean to sustain global primacy in the $21^{\text {st }}$ Century. Thus, it was prerequisite for the United States to sustain control over Eurasia. After the collapse of the Soviet Union, the United States 
emerged as the sole global power. Focusing upon the importance of Eurasia, Brzezinski indicated that American global primacy was directly dependent upon the effective presence of United States on Eurasian land [23]. The core of his theory lies in the eastward expansion of West especially in the newly independent post-Soviet region.

Giving importance to geographic location and its place in foreign policy making of any state Brzezinski pointed out that location determines immediate priorities of the state. As economic, political, and military power of any state is directly proportional to its, geopolitical influence, geopolitical interest, and involvement in affairs of immediate and distant neighbours. Thus dividing states based on dominance, and their strategic location, he came up with the concept of Active Geostrategic Players and Geostrategic Pivot. Active Geostrategic Players are those states who have the Capacity and the National will to implement power or influence away from their borders in order to alter- to a degree that affects America's interest- the existing geopolitical state of affair [23, p.40]. On the other hand, Geopolitical Pivots are the states whose importance is derived not from their power and motivation but rather from their sensitive location and from the consequence of their potentially vulnerable condition for the behaviour of geostrategic players [23, p. 41].

Geopolitical pivots are determined by their geography, which in some cases gives them a special role either in denying access to important areas or in denying resources to a significant player. In some cases, a geopolitical pivot may act as a defensive shield for vital states or even a region. Although Brzezinski identified France, Germany, Russia, China, and India as the major Active Geostrategic Players and Ukraine, Azerbaijan, South Korea, Turkey, and Iran as the critically important geopolitical pivots. He also mentioned that this list was neither permanent nor fixed, and could be changed according to the situation [23].

While focusing upon the growing importance of Central Asia states, he underlined that Kazakhstan and Uzbekistan to emerge as an important geopolitical pivot in future [23, p.48]. Series of events since then i. e. discovery of huge Caspian reserves, twin tower attack in the United States in 2001, rise of Taliban, American army presence in Afghanistan, war on terror, political and economic instability in the region, oil shortage etc., brought this region into prime focus of Active Geostrategic Players especially leading to American involvement in this region.

Stressing upon geopolitical importance of the region in his work he mentioned, "Eurasia is the globe's largest continent and geopolitically axial. A power that dominates Eurasia would control two of the world's most advances and economically productive regions. The control over Eurasia would almost automatically entails Africa's subordination, rendering the Western Hemisphere and Oceania geopolitically peripheral to the world's central continent. Since Eurasia is too big to be politically one. It is the chessboard on which the struggle for global primacy continues to be played" [23, p.31].

To prevent Russian efforts of regaining its superpower status he recommended a Trans-Eurasian Security system which is an expanded NATO and triangular political security dialogue between America, China, and Japan. Regardless of the limitations of his theory, occurrence of the September 11 incident, dramatically shifted Washington's perspective and engagements in the region which were clearly influenced by Brzezinski's strategy.

Prior to the September 11 incident United States commitments in Central Asian states focused checking the regional instability and terrorist activities, development of the 
democratic institution, respect for human rights and utilizing the vast natural reserves of oil and natural gas for achieving its geopolitical need in the region. Brzezinski's theory influenced the discourse in academic circle and was considered by the US foreign policymaking towards Eurasia and particularly Central Asia.

Based on geostrategic capacity and geographical space, Brzezinski divided Eurasia into four regions i. e. Middle space (dominated by Russia), West space (Europe, predominance by America), South space (the Caucasus Central Asian countries) and East space (China, Japan and both Koreas) [23]. Moreover, it was necessary for America to be politically active in this region through its policies, supporting newly independent states in order to strengthen their political and economic independence from Russia. Within the larger 'Eurasia', Brzezinski gave importance to the so called middle space in Eurasia which covers the former Soviet and East European countries [24, p. 15].

\section{Conclusion}

It is not simply the region but also the theories which continually speaks of the strategic importance of the region and influence policy makers to look up to the matter with the same prism. Mackinder inspired generations of strategic studies across the globe. In the post-war era, the American strategist continued to view the world as seen by Mackinder to proliferate their foreign policy of containment in the Eurasian landmass. Especially after the Soviet collapse, there has been a strong revival of Mackinder's ideas to justify competition for influence in Eurasian Heartland. His theory justifies the importance of the study area, vis-à-vis the quest for power projection by various hegemonic states of the world. Later on, Brzezinski carried forward Mackinder's ideas during the post-cold war period which acted as the cornerstone of foreign policy towards Eurasia during Clinton and Bush administration for United States' east ward expansion.

Power politics in the region for dominance correctly depicts the centrality of the region in the foreign policy of major leaders of the world. Presently China is the biggest trading partner with most of the Central Asian countries. Chinese ambition in Eurasia through various initiatives is to challenge American ambition in the region and on the globe, thus following the path suggested by Mackinder - Who will rule the Heartland will rule World Island and the world eventually. Some of the Central Asian states profited with the new attention and used available grants and investments as well as geopolitical position in their favour. For example, in such short span of time, Kazakhstan has evolved as a modern and prosperous economy, which is currently among the top 50 developed economies of the world. An active member in CSTO, SCO, and NATO, Kazakhstan can play a very important role in maintaining regional security and can act as a bridge between East and West.

\section{References}

1. Bassin, M. (1987), Imperialism and the nation state in Friedrich Ratzel's political geography, Progress in Human Geography, vol. 11, iss. 4, pp. 437-495.

2. Kristof, K. D. (1960), The Origin and Evolution of Geopolitics, The Journal of Conflict Resolution, vol. 4 , iss. 1, pp. $15-51$.

3. Kullberg, A. K. (2000), The Return of Heartland, Eurasian Politician, iss. 1, pp. 1-25.

4. Kelly, P. (2019), Rescuing Classical Geopolitics, Geopolitics, History and International Relations, vol. 11 (1), pp. 41-58. 
5. Sloan, G. (2017), Geopolitics, Geography and Strategic History. New York and London: Routledge.

6. Sharshenova, A. (2009), Political construction of geography: US and Russian concept of Central Asia, POLIS Journal, iss. 2. Available at: http://www.polis.leeds.ac.uk/assets/files/students/student-journal/mawinter-09/aijan-sharshenova-winter-09.pdf (accessed: 11.12.2013).

7. Chapman, B. (2018), Sloan on Geopolitics, Geography and Strategic History in Geopolitics, Geopolitics, History and International Relations, vol. 10 (2), pp. 7-16.

8. Labban, M. (2009), The Struggle for the Heartland: Hybrid Geopolitics in the Trans-Caspian, Geopolitics, vol. 14, iss. 1, pp. 1-25.

9. Sprinz, D. F. and Nahmias, Y.W. (2004), Models, Numbers and Cases: Methods for studying International Relations. Ann Arbor: The University of Michigan Press.

10. Mackinder, H. J. (1904), The Geographical Pivot of History, The Geographical Journal, vol. 23, iss. 4, pp. 421-437.

11. Scott, M. and Alcenat, W. (2008), Revisiting the Pivot: The Influence of Heartland Theory in the Great Power Politics. Available at: https://www.creighton.edu/fileadmin/user/CCAS/departments/PoliticalScience/MVJ/docs/The_Pivot_-_Alcenat_and_Scott.pdf (accessed: 15.06.2019).

12. Matikeeva, S. (2005), Mackinder's Legacy: Was it a Prophesy? Central Asia and the Caucasus, vol. 36, iss. 4 , pp. $24-28$.

13. Hagan, K. (2006), Global Geostrategy: Mackinder and the Defense of the West, Journal of Military History, vol. 10, iss. 2, pp. 521-523.

14. Report of National Security Strategy of United States (1988). Available at: http://nssarchive.us/ NSSR/1988.pdf (accessed: 18.05.2019).

15. Iseri, E. (2009), The US Grand Strategy and the Eurasian Heartland in the Twenty-First Century, Geopolitics, vol. 14, iss. 1, pp. 26-46.

16. Jiali, M. (1999), Central Asia: Geostrategic and Big Power Policies, Contemporary Central Asia, vol. 3 , iss. 1, pp. 39-46.

17. Haass, R. (2003), Why Washington welcomes China's rise, South China Morning Post. Available at: https://carnegieendowment.org/pdf/files/pg2.pdf (accessed: 29.05.2019).

18. Sutter, R. (2003), China Remains Wary of the U.S. Led World Order, Yale Global Online. Available at: https://yaleglobal.yale.edu/content/china-remains-wary-us-led-world-order (accessed: 12.03.2019).

19. Shanghai Cooperation Organization (2018), Information Report following the meeting of the Council of Head of State of the Shanghai Cooperation Organization Member States. Available at: http://eng.sectsco. org/news/20180610/443710.html (accessed: 15.06.2019).

20. Harper, T. (2017), Towards an Asian Eurasia: Mackinder's Heartland Theory and the return of China to Eurasia, Cambridge Journal of Eurasian Studies, iss. 1, pp. 1-27.

21. Abilov, S. (2012), The "New Great Game" Over the Caspian Region: Russia, the USA, and China in the Same Melting Po, Khazar Journal of Humanities and Social Sciences, vol. 15, iss. 2, pp. 29-59.

22. Sarker, N. I. et al. (2018), One Belt One Road Initiatives of China: Implications for Future of Global Development, Modern Economy, vol. 9, no. 4, pp. 623-638.

23. Brzezinski, Z. (1997), The Grand Chessboard. New York: Basic Books Publishers.

24. Patnaik, A. (2016), Central Asia: Geopolitics security and stability. London and New York: Routledge.

Received: August 4, 2020

Accepted: September 15, 2020

Author's information:

Akanksha Singh — PhD, Independent Researcher; akankshaOSR@gmail.com 